\title{
Pendapatan Masyarakat pada Komponen Silvopasture dan Agrisilvikultur Kecamatan Parangloe Kabupaten Gowa
}

\author{
Muthmainnah ${ }^{1 *}$, Irma Sribianti ${ }^{1}$ \\ ${ }^{1}$ Staf Pengajar Program Studi Kehutanan Universitas Muhammadiyah, Makassar \\ *Email: muthmainnah.zainuddin@unismuh.ac.id
}

\begin{abstract}
This study aims to (1) identify the types of income from the components of silvopasture and agrisilvikulture (2) to know the income of farmers from the components of silvopasture and agrisilvikulture. This study was conducted for 3 months from April to July 2016. The respondent sample is a member of the community who earn income from the components of silvopasture and agrisilvikulture. Sampling technique conducted in this research is census method that is 20 head of family from population to be sample. The results showed that the farmers who apply the silvopasture component combine the plant component of forestry in the form of Goomar teak (Gmelina arborea) with an average income of Rp.3.310.773/year and livestock components in the form of cattle Rp. 2.307.727/year. The agrisilvikulture component is a forestry component of Goomar teak (Gmelina arborea) with an average income of Rp.2.155.889/year combined with agricultural crops such as rice (Oryza sativa L.) with an average income of Rp. 1.372.500/year, corn (Zea mays L.) of Rp. 4.232.000/year, cassava (Manihot utilissima) Rp. 4.347.500 / year, long beans (Vigna sinensis L.) of Rp. 627,500 / year, cucumber (Cucumis sativus L.) of Rp. 505.000/year and bitter melon (Momordica charantia L.) of Rp. 530,000/year. Silvopasture component income is Rp.61.803.500/year with an average of Rp.5.618.500/year or 47,08\%. While the results from agrisilvikultur with a value of $R p 56.834 .000 / y e a r$ with an average of $R p \quad 6.314 .889 /$ year or $52,92 \%$. This shows that the audiovisual income is higher than that of silvopasture.
\end{abstract}

Keywords: Income, Silvopasture, Agrisilvikulture

\section{PENDAHULUAN}

Hutan adalah kumpulan pepohonan yang tumbuh rapat beserta tumbuh-tumbuhan memanjat dengan bunga yang beraneka warna yang berperan sebagai sumber kehidupan di muka bumi, terutama kehidupan generasi mendatang. Untuk mencegah kesalahan dalam pengelolaan hutan, maka fungsi hutan harus dipelejari dan dimengerti secara utuh. Agroforestri adalah nama kolektif untuk sistem dan teknologi penggunaan lahan, di mana tanaman berkayu (pohon, perdu, palmae, bambu) di tanam secara sengaja pada unit manajemen lahan yang sama dengan tanaman pertanian dan/atau ternak. Di dalam sistem agroforestri senantiasa terjadi interaksi ekologi maupun ekonomi di antara komponen-komponennya, sedangkan secara teoritis setiap sistem agroforestri memiliki tujuan penting yaitu produktivitas

Sistem agroforestri adalah suatu sistem pertanian dimana pepohonan ditanam secara tumpang-sari dengan satu atau lebih jenis tanaman semusim. Pepohonan bisa ditanam sebagai pagar mengelilingi petak lahan tanaman pangan, secara acak dalam petak lahan, atau dengan pola lain misalnya berbaris dalam larikan sehingga membentuk lorong/pagar, pola pagar adalah pola pengembangan tanaman kehutanan sebagai pagar di tepi lahan secara melingkar. Pola ini banyak ditemukan pada lahan pekarangan dan lahan pertanian yang subur.

Pola agroforestri juga memungkinkan penanaman dengan pola monokultur, walaupun keluarga merupakan pihak yang paling menentukan keputusan dalam pengusahaan hutan rakyat dengan pola agroforestri, selain itu keberadaan hutan rakyat dengan pola agroforestri supaya turut menyumbang pasokan kayu bagi industri perkayuan, di samping itu sebagai sarana dalam upaya peningkatan kesejahteraan masyarakat khususnya yang tinggal di pedesaan.

Desa Belapungranga Kecamatan Parangloe Kabupaten Gowa adalah salah satu di Provinsi Sulawesi Selatan. Pola penggunaan lahan oleh penduduk pada desa tersebut melakukan pengolahan lahan dengan berbagai pola agroforestry pada lahan milik rakyat yang 
luasannya kurang lebih 40 hektar. Besarnya pendapatan pada berbagai pola agroforestri yang dilakukan penduduk Desa Belapungranga perlu diketahui sebagai bahan untuk pemilihan alternatif pola agroforestri pada pemanfaatan lahan yang mulai terbatas ketersediaannya dengan menanam berbagai jenis komoditi baik tanaman kehutanan, pertanian maupun pakan ternak pada suatu luasan lahan yang berbeda-beda.

Penerapan sistem agroforestri disuatu daerah memiliki prospek yang baik dimana agroforestri sebagai suatu sistem yang memadukan berbagai jenis tanaman dalam satu lahan akan memungkinkan naiknya produktivitas hasil panen setiap tanaman (Mahendra, 2009). Meningkatnya total produksi per satuan luas lahan dengan penerapan sistem agroforestri akan meningkatkan pendapatan masyarakat. Kajian mengenai pendapatan masyarakat dalam pengelolaan agroforestri dan pola agroforestri yang diterapkan oleh petani menjadi dibutuhkan guna mengetahui seberapa besar pengaruh pengelolaan agroforestri tersebut terhadap pendapatan masyarakat. Dengan semakin besar pendapatan masyarakat akan menjadi pendorong minat dan usaha masyarakat untuk terus mengembangkan hutan rakyat melalui sistem pengelolaan agroforestri. Berdasarkan uraian tersebut maka penelitian tentang pendapatan petani dalam pengelolaan sistem agroforestri menjadi sangat penting. Tujuan penelitian ini adalah mengidentifikasi komponen agroforestry pada hutan rakyat di Kecamatan Parangloe dan menghitung pendapatan petani dari setiap komponen agroforestry tersebut.

\section{METODE PENELITIAN}

\subsection{Waktu dan Tempat}

Penelitian ini dilakukan mulai bulan April sampai dengan Juni 2016. Penelitian ini dilaksanakan di Desa Belapungranga Kecamatan Parangloe Kabupaten Gowa dengan tema penelitian Pola Agroforestri Pada Hutan Rakyat di Desa Belapungranga Kecamatan Parangloe Kabupaten Gowa.

\subsection{Teknik Pengambilan Data}

Populasi adalah masyarakat dengan pola agroforestri yang memperoleh pendapatan.Sampel responden adalah anggota masyarakat yang memperoleh pendapatan dari pola agroforastri. Teknik pengambilan sampel yang dilakukan dalam penelitian ini adalah metode sensus yaitu 20 kepala keluarga dari populasi dijadikan sampel. Penelitian ini yang dijadikan sampel adalah petani yang menerapkan pola agroforestri di Desa Belapungranga Kecamatan Parangloe Kabupaten Gowa.

\subsection{Analisisi Data}

Untuk menghitung pendapatan masyarakat berdasarkan harga pasar (Market Price) dengan rumus sebagai berikut:

$$
I=T R-T C
$$

Dimana :

$$
\begin{array}{ll}
\text { I } & =\text { pendapatan bersih } \\
\text { TR } & =\text { total penerimaan } \\
\text { TC } & =\text { total biaya }
\end{array}
$$

Dimana :

$$
\begin{array}{ll}
\mathrm{TR} & =\text { total penerimaan } \\
\mathrm{Qi} & =\text { jumlah produksi } \\
\mathrm{Pi} & =\text { harga produksi }
\end{array}
$$

$$
\mathrm{TR}=\sum_{i=1}^{n} \mathrm{Qi} . \mathrm{Pi}
$$




$$
\mathrm{TC}=\sum_{i=2}^{n} \mathrm{Xi} . \mathrm{Pxi}
$$

Dimana :

$$
\begin{array}{ll}
\mathrm{TC} & =\text { total biaya } \\
\mathrm{Xi} & =\text { jenis input biaya } \\
\mathrm{Pxi} & =\text { harga input biaya }
\end{array}
$$

\section{HASIL PENELITIAN}

\subsection{Jenis Komponen Agroforestri}

Berdasarkan hasil identifikasi di lapangan terdapat dua jenis komponen agroforestri yang secara umum digunakan oleh masyarakat yaitu silvopasture dan agrisilvikultur.

\section{a. Komponen Silvopastura}

Silvopasture adalah kombinasi antara komponen atau kegiatan kehutanan dan peternakan. Komponen silvopastura yang ada di Desa Belapungranga Kecamatan Parangloe Kabupaten Gowa yang dikelolah oleh petani yaitu pada komponen kehutanan petani menanam kayu jati putih dan komponen peternakannya yaitu sapi. Peternakan sapi yang di kelola oleh Di Desa Belapungranga Kecamatan Parangloe Kabupaten Gowa adalah milik pribadi dimana kandangnnya terletak dalam kebun petani. Pada saat musim kemarau pakan dari sapi berasal dari rumput gajah yang di tanam di kebun petani sedangkan pada musim hujan pakan berasal dari jerami dan batang jagung hal ini yang menyebabkan petani tidak mengeluarkan biaya terlalu besar untuk pakan sapi. Pola silvopasture di Desa Belapungranga Kecamatan Parangloe Kabupaten Gowa dapat dilihat pada Gambar 1.

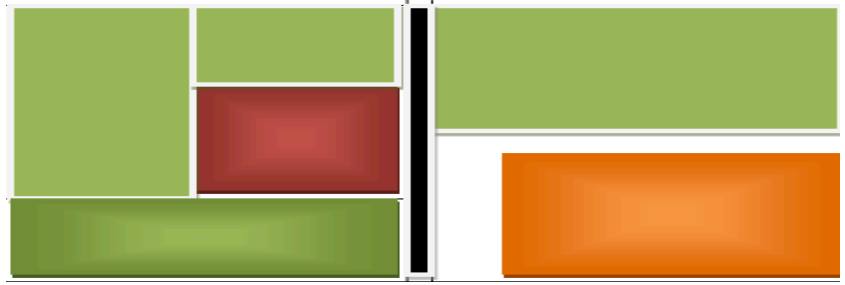

Gambar 1. Komponen silvopasture

Keterangan:

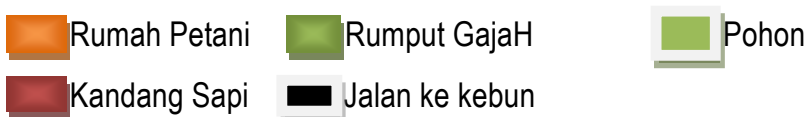

\section{b. Komponen Agrisilvikultur}

Agrisilvikiltur yaitu sistem agroforestri yang mengkombinasikan komponen kehutanan dengan tanaman pertanian /perkebunan. Sistem agrisilvikultur yang diterapkan oleh petani dengan mengkombinasikan tanaman kehutanan yaitu jati putih (Gmelina arborea) dengan tanaman pertanian / perkebunan yaitu jagung (Zea mays L), padi (Oryza sativa L), mentimun (Cucumis sativus L), ubi kayu (Manihot utilissima), pare (Momordica charantia), kacang panjang (Vigna sinensis L.). Hasil pengamatan pada kebun rakyat yang dimiliki oleh petani terdapat beberapa pola tanam yang berbeda berdasarkan susunan komponen jenis yang ada di dalamnya dimana pada umumnya yang dikembangkan oleh petani setempat pola penanaman yang dilakukan untuk tanaman tersebut adalah pola berkelompok. 


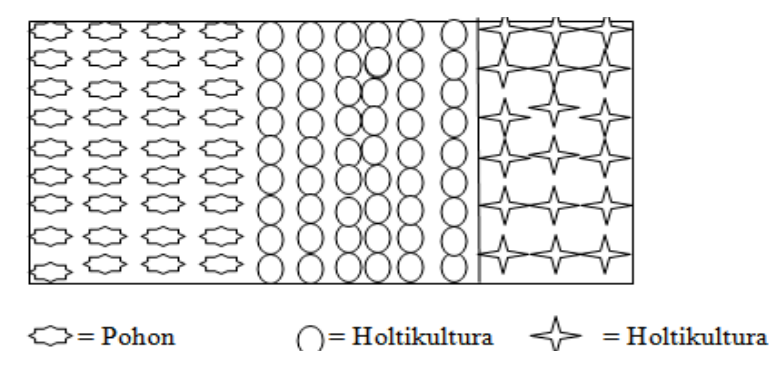

Gambar 2. Pola Berkelompok Pada Agrisilvikultur

\subsection{Pendapatan}

\section{a. Komponen Silvopasture}

Silvopasture yang dikelola adalah kombinasi antara tanaman komponen kehutanan berupa jati putih dan komponen peternakan berupa sapi, petani menjual sapi ketika berumur 2 tahun dengan harga Rp.7.000.000/ekor. Pendapatan petani dari peternakan sapi dapat dilihat pada Tabel 1.

Tabel 1. Pendapatan Peternakan (Sapi)

\begin{tabular}{llrrr}
\hline No & Nama Responden & $\begin{array}{c}\text { Penerimaan } \\
\text { (Rp/Tahun) }\end{array}$ & $\begin{array}{c}\text { Biaya } \\
\text { (Rp/Tahun) }\end{array}$ & $\begin{array}{c}\text { Pendapatan } \\
\text { (Rp/Tahun) }\end{array}$ \\
\hline $\mathbf{1}$ & Syarif dg Mone & 10.500 .000 & 9.180 .000 & 1.320 .000 \\
$\mathbf{2}$ & H dg Nyomba & 7.000 .000 & 4.490 .000 & 2.510 .000 \\
$\mathbf{3}$ & Madding dg Taba & 10.500 .000 & 7.910 .000 & 2.590 .000 \\
$\mathbf{4}$ & J dg Nai & 10.500 .000 & 9.100 .000 & 1.400 .000 \\
$\mathbf{5}$ & B dg Bella & 10.500 .000 & 8.920 .000 & 1.580 .000 \\
$\mathbf{6}$ & Dg Tika & 10.500 .000 & 7.930 .000 & 2.570 .000 \\
$\mathbf{7}$ & Dg Sijaya & 14.000 .000 & 9.145 .000 & 4.855 .000 \\
$\mathbf{8}$ & Dg Tangnga & 7.000 .000 & 4.390 .000 & 2.610 .000 \\
$\mathbf{9}$ & Abd Rajab & 10.500 .000 & 9.350 .000 & 1.150 .000 \\
$\mathbf{1 0}$ & Dg rate & 7.000 .000 & 5.140 .000 & 1.860 .000 \\
$\mathbf{1 1}$ & Dg.Ngupa & 7.000 .000 & 4.060 .000 & $\mathbf{2 . 9 4 0 . 0 0 0}$ \\
& & & & \\
\hline Jumlah & & & $\mathbf{2 5 . 3 8 5 . 0 0 0}$ \\
\hline Rata - rata & & & $\mathbf{2 . 3 0 7 . 7 2 7}$ \\
\hline
\end{tabular}

Berdasarkan Tabel 1 menunjukkan bahwa petani yang memiliki pendapatan paling tinggi yaitu Dg Sijaya Rp 4.855.000/Tahun yang memiliki jumlah sapi 13 ekor dan setiap 2 tahun menjual sapinya. Dan pada tahun 2016 Dg Sijaya menjual sapi sebanyak 4 ekor dengan harga Rp 7.000.000/ekor jumlah penerimaan $\mathrm{Rp} 28.000 .000 / 2$ Tahun dengan rata-rata penjualan $\mathrm{Rp}$ 14.000.000/tahun dikurangi dengan biaya berupa modal awal dari sapi, tali pengikat, kandang sapi, ember dan garam Rp 9.145.000/tahun. Petani Dg Sijaya menerima pendapatan yang paling tinggi karena jumlah sapi yang dijual setiap tahun lebih banyak di bandingkan dengan petani lain.

Komponen kehutanan kayu jati putih. Petani akan menjual kayu jati putih ketika berumur 5 tahun dan di jual dengan hitungan pohon dengan harga Rp 70.000 /pohon tanpa mengeluarkan biaya angkutan dan biaya tebang. Pendapatan petani dari tanaman kehutanan dapat dilihat pada Tabel 2. Biaya tebang di tanggung oleh pengepul, pengepul yang membeli kayu ada 2 yaitu dari luar desa Belapungranga dan pengusaha meubel yang ada di Desa Belapungranga, petani menjual kayu saat musim panas karena pada musim hujan akses jalan yang sulit berupa lumpur. 
Tabel 2. Pendapatan Kehutanan (Jati Putih)

\begin{tabular}{llcrr}
\hline No & Nama Responden & $\begin{array}{c}\text { Penerimaan } \\
\text { (Rp/Tahun) }\end{array}$ & $\begin{array}{c}\text { Biaya } \\
\text { (Rp/Tahun) }\end{array}$ & $\begin{array}{r}\text { Pendapatan } \\
\text { (Rp/Tahun) }\end{array}$ \\
\hline $\mathbf{1}$ & Syarif dg Mone & 10.332 .000 & 960.000 & 9.372 .000 \\
$\mathbf{2}$ & H dg Nyomba & 1.610 .000 & 697.500 & 912.500 \\
$\mathbf{3}$ & Madding dg Taba & 4.396 .000 & 922.500 & 3.473 .500 \\
$\mathbf{4}$ & J dg Nai & 4.354 .000 & 852.500 & 3.501 .500 \\
$\mathbf{5}$ & B dg Bella & 4.578 .000 & 852.500 & 3.725 .500 \\
$\mathbf{6}$ & Dg Tika & 4.200 .000 & 845.000 & 3.355 .000 \\
$\mathbf{7}$ & Dg Sijaya & 1.792 .000 & 697.500 & 1.094 .500 \\
$\mathbf{8}$ & Dg Tangnga & 924.000 & 690.000 & 234.000 \\
$\mathbf{9}$ & Abd Rajab & 4.438 .000 & 852.500 & 3.585 .500 \\
$\mathbf{1 0}$ & Dg rate & 4.032 .000 & 845.000 & 3.187 .000 \\
$\mathbf{1 1}$ & Dg ngupa & 4.830 .000 & 852.500 & 3.977 .500 \\
& & & \\
\hline Jumlah & & & 36.418 .500 \\
\hline
\end{tabular}

Berdasarkan Tabel 2 bahwa petani yang memiliki pendapatan yang paling tinggi adalah Syarif Dg Mone yang memiliki pendapatan Rp 9.582.000/Tahun dengan luas lahan 2,40 Ha jumlah pohon yang dijual sebanyak 738 dengan harga Rp 70.000/pohon dengan jumlah penerimaan 10.332.000/Tahun dikurangi dengan jumlah biaya berupa polybag, biaya tanam, parang, cangkul, alat semprot dan pestisida, sehingga biaya yang di keluarkan sebesar Rp 960.000/Tahun. Petani Syarif Dg Mone menerima pendapatan paling tinggi karena memiliki lahan yang cukup luas yang ditanami kayu jati putih dibanding petani yang lain.

\section{b. Komponen Agrisilvikultur}

Pada pola agrisilvikultur petani yang mengelolah sebanyak 9 orang petani mengkombinasikan komponen kehutanan dengan komponen pertanian. Komponen kehutanan yang ditanam oleh petani yaitu jati putih yang di padukan dengan tanaman pertanian seperti padi, jagung, ubi kayu, kacang panjang, mentimun dan pare. Pendapatan tanaman kehutanan dapat diihat pada Tabel 3 .

Tabel 3. Pendapatan Kehutanan (Jati Putih) di Desa Belapungranga.

\begin{tabular}{llcrr}
\hline No & Nama responden & $\begin{array}{c}\text { Penerimaan } \\
\text { (Rp/Tahun) }\end{array}$ & $\begin{array}{c}\text { Biaya } \\
\text { (Rp/Tahun) }\end{array}$ & $\begin{array}{r}\text { Pendapatan } \\
\text { (Rp/Tahun) }\end{array}$ \\
\hline $\mathbf{1}$ & Misran Dg Tawang & 4.340 .000 & 712.500 & 3.627 .500 \\
$\mathbf{2}$ & Muh Ali Dg Rate & 1.358 .000 & 690.000 & 668.000 \\
$\mathbf{3}$ & Asis Dg Nyikko & 1.148 .000 & 690.000 & 458.000 \\
$\mathbf{4}$ & Syarifuddin Dg Situru & 3.822 .000 & 705.000 & 3.117 .000 \\
$\mathbf{5}$ & Dg Ati & 3.010 .000 & 723.000 & 2.287 .000 \\
$\mathbf{6}$ & Dg Sarro & 4.900 .000 & 712.500 & 4.187 .500 \\
$\mathbf{7}$ & Abdullah & 616.000 & 147.500 & 468.500 \\
$\mathbf{8}$ & Jamaluddin Dg Ngewa & 1.792 .000 & 697.500 & 1.094 .500 \\
$\mathbf{9}$ & Dg Timung & 4.200 .000 & 705.000 & 3.495 .000 \\
& & & \\
\hline JUMLAH & & & \\
\hline Rata - rata & & & \\
\hline
\end{tabular}

Sumber :Data Primer Setelah Diolah 2016 
Berdasarkan Tabel 3 menunjukkan bahwa petani dengan pola agrisilvikultur yang memiliki pendapatan tertinggi yaitu $\mathrm{Dg}$ Sarro sebanyak Rp 4.187.500/Tahun dengan luas lahan 1 hektar dengan jumlah pohon 350 pohon dengan penerimaan selama 5 tahun $\mathrm{Rp} 24.500 .000$ dan dijadikan pendapatan pertahun maka penerimaan Rp 4.900.000 dikurangi dengan biaya berupa polybag, parang, cangkul, alat semprot dan pestisida jadi biaya yang dikeluarkan yaitu Rp 712.500/Tahun sehingga petani menghasilkan pendapatan sebesar Rp 4.187.500/Tahun petani Dg Sarro menerima pendapatan paling tinggi karena memiliki luas lahan yang cukup luas yang ditanami jati putih.

Petani menanam tanaman pertanian yaitu padi hanya 1 kali setahun pada saat musim hujan. Waktu tanam mulai bulan januari sampai maret karena termasuk lahan kering, pada saat panen petani hanya menjual padi dengan setengah dari yang didapatkan dan setengahnya lagi untuk konsumsi pribadi. Cara penjualan padi dijual perkilo dengan harga Rp 3.700/kilo, pada penanaman padi petani memberikan pupuk urea dengan takaran yang berbeda- beda setiap petani dan pada serangan hama petani memberikan pestisida dangke dengan takaran 1 tutup botol dangke / 15 liter air pendapatan petani dapat dilihat pada Tabel 4 .

Tabel 4. Pendapatan Pola Agrisilvikultur (Padi)

\begin{tabular}{llrrr}
\hline No & Nama responden & $\begin{array}{c}\text { Penerimaan } \\
\text { (Rp/Tahun) }\end{array}$ & $\begin{array}{c}\text { Biaya } \\
\text { (Rp/Tahun) }\end{array}$ & \multicolumn{1}{c}{$\begin{array}{c}\text { Pendapatan } \\
\text { (Rp/Tahun) }\end{array}$} \\
\hline $\mathbf{1}$ & Misran Dg Tawang & 2.960 .000 & 1.750 .000 & 1.210 .000 \\
$\mathbf{2}$ & Muh ali Dg Rate & 1.480 .000 & 905.000 & 575.000 \\
$\mathbf{3}$ & Syarifuddin Dg Situru & 4.440 .000 & 1.535 .000 & 2.905 .000 \\
$\mathbf{4}$ & Dg Ati & 740.000 & 265.000 & 475.000 \\
$\mathbf{5}$ & Abdullah & 1.480 .000 & 830.000 & 650.000 \\
$\mathbf{6}$ & Jamaludin Dg Ngewa & 4.440 .000 & 2.020 .000 & 2.420 .000 \\
\hline Jumlah & & & 8.235 .000 \\
\hline Rata- rata & & & 1.372 .500 \\
\hline
\end{tabular}

Sumber: Data Primer Setelah Diolah 2016

Berdasarkan Tabel 4 menunjukkan bahwa petani yang memiliki pendapatan yang paling tinggi yaitu Syarifuddin Dg Situru dengan penerimaan Rp 4.440.000/Panen dikurangi biaya berupa biaya transpor, pupuk urea, sabit dan biaya sewa traktor jadi jumlah biaya sebesar Rp 1.535.000/Panen maka pendapatan yang diterima Syarifuddin dg Situru sebesar Rp 2.905.000/Panen petani Syarifuddin Dg Situru menerima pendpatan yang paling tinggi karena memiliki lahan yang lebih luas sehingga produksi lebih tinggi dibanding petani lain. Pada sistem agrisilvikultur petani juga menanam mentimun sebagai kebutuhan rumah tangga selain dari itu petani juga menjual mentimun, penanaman mentimun hanya 1 kali setahun yaitu penanaman bulan Februari di panen bulan April dalam penanaman 1 kali dalam setahun petani memanen mentimun sebanyak 5 kali dan pada panen pertama petani lebih banyak di banding panen selanjutnya petani menjual ke pedagan buah seharga Rp 500 / buah, pendapatan petani dapat dilihat pada Tabel 5 .

Tabel 5. Pendapatan Petani Pola Agrisilvikultur (Mentimun)

\begin{tabular}{llrrr}
\hline No & Nama responden & $\begin{array}{c}\text { Penerimaan } \\
\text { (Rp/Tahun) }\end{array}$ & $\begin{array}{c}\text { Biaya } \\
\text { (Rp/Tahun) }\end{array}$ & \multicolumn{1}{c}{$\begin{array}{c}\text { Pendapatan } \\
\text { (Rp/Tahun) }\end{array}$} \\
\hline $\mathbf{1}$ & Muh ali Dg Rate & 1.045 .000 & 370.000 & 675.000 \\
$\mathbf{2}$ & Dg Ati & 760.000 & 220.000 & 540.000 \\
$\mathbf{3}$ & Dg Timung & 565.000 & 265.000 & 300.000 \\
\hline Jumlah & & & 1.515 .000 \\
\hline Rata- rata & & & 505.000 \\
\hline
\end{tabular}


Berdasarkan Tabel 5 menunjukkan bahwa Petani yang mendapatkan pendapatan yang paling tinggi yaitu Muh Ali Dg Rate yaitu Rp 675.000/Panen dengan luas lahan 0,20 dengan jumlah buah yang dijual sebanyak 2090 buah maka penerimaan yang diterima oleh petani sebanyak Rp 1.045.000/Panen maka dari itu di kurangi dengan biaya berupa bibit mentimun, pupuk kandang, dan pupuk urea, pestisida decies jadi jumlah biaya sebesar Rp 370.000/Panen. Petani Muh Ali Dg Rate menerima pendapatan paling tinggi karena lahan yang dimiliki cukup luas di bandingkan dengan petani yang lain. Sistem agrisilvikultur petani juga menanam ubi kayu pada lahan yang di kelilingi pohon sebagai tanaman pagar, bibit ubi kayu diperoleh dari penanaman sebelumnya. Petani juga memberikan pupuk untuk ubi kayu yaitu pupuk urea, pupuk Za, dan pupuk Npk. Petani akan memanen ubi pada umur 8 bulan kepada pedagang yang datang dengan harga Rp 500/ kilo (basah), dalam 1 hektar petani mendapatkan 15 ton atau 15000 kilo. Pendapatan petani ubi kayu dapat dilihat pada Tabel 6 .

Tabel 6. Pendapatan Pola Agrisilvikiltur (Ubi Kayu)

\begin{tabular}{llrrr}
\hline No & Nama responden & $\begin{array}{c}\text { Penerimaan } \\
\text { (Rp/Tahun) }\end{array}$ & $\begin{array}{c}\text { Biaya } \\
\text { (Rp/Tahun) }\end{array}$ & \multicolumn{1}{c}{$\begin{array}{c}\text { Pendapatan } \\
\text { (Rp/Tahun) }\end{array}$} \\
\hline $\mathbf{1}$ & Dg Sarro & 7.500 .000 & 340.000 & 7.160 .000 \\
$\mathbf{2}$ & Abdullah & 1.875 .000 & 340.000 & 1.535 .000 \\
$\mathbf{3}$ & Jamaluddin Dg Ngewa & 1.875 .000 & 340.000 & 1.535 .000 \\
$\mathbf{4}$ & Dg Timung & 7.500 .000 & 340.000 & 7.160 .000 \\
\hline Jumlah & & & 17.390 .000 \\
\hline Rata- rata & & & 4.347 .500 \\
\hline
\end{tabular}

Berdasarkan Tabel 6 menujukkan bahwa pendapatan hampir sama karena luas lahan yang dimiliki petani dan hasil yang didapatkan sama tetapi cara pemeliharaan seperti pemupukan yang berbeda.Petani menanam kacang panjang sebagai kebutuhan rumah tangga juga bisa menambahkan pendapatan, petani menanam disekitaran pohon jati putih, penanaman dilakukan pada saat musim hujan cara menbuat bedengan dan diberi pancang yang terbuat dari bambu sebagai tempat melilitnya. Pendapatan kacang panjang dapat dilihat pada Tabel 7.

Tabel 7. Pendapatan Kacang Panjang

\begin{tabular}{llrrr}
\hline No & Nama responden & $\begin{array}{c}\text { Penerimaan } \\
\text { (Rp/Tahun) }\end{array}$ & $\begin{array}{c}\text { Biaya } \\
\text { (Rp/Tahun) }\end{array}$ & \multicolumn{1}{c}{$\begin{array}{c}\text { Pendapatan } \\
\text { (Rp/Tahun) }\end{array}$} \\
\hline $\mathbf{1}$ & Dg Ati & 1.045 .000 & 225.000 & 820.000 \\
$\mathbf{2}$ & Misran Dg Tawang & 760.000 & 325.000 & 435.000 \\
\hline Jumlah & & & 1.255 .000 \\
\hline Rata- rata & & & 627.500 \\
\hline
\end{tabular}

Tabel 7 menunjukkan bahwa pada pola agrisilvikultur ada 2 petani yang menanam kacang panjang dan petani yang memiliki pendapatan yang tinggi yaitu Misran Dg Tawang dengan 3 kali panen. Panen pertama $50 \mathrm{ikat}$, panen kedua $35 \mathrm{ikat}$, dan panen ketiga 20 ikat dengan jumlah ikat/3 panen 105 ikat yang dijual dengan harga 10.000 /ikat kepada pedagang sayur maka penerimaan Rp 1.050.000/Panen dikurangi dengan biaya berupa pupuk, transpor kacang panjang dan bibit kacang panjang jadi jumlah biaya sebesar Rp 225.000/Panen maka pendapatan yaitu Rp 820.000/Panen. Petani Misran Dg Tawang menerima pendapatan paling tinggi karena memiliki lahan yang cukup luas sehingga produksi yang dihasilkan lebih banyak dibanding petani lain.

Sistem agrisilvikultur lain petani menanam jagung hibrida dengan pohon jati sebagai pagar penanaman jagung ini dimulai bulan januari - maret dan petani menjual jagungnya kepada pedagang dengan harga 3.000 / kilo. Penanaman jagung dilakukan pada bulan 2-4 dan hanya sekali dalam setahun, pendapatan petani jagung dapat dilihat pada Tabel 8 . 
Tabel 8. Pendapatan petani jagung

\begin{tabular}{llrrr}
\hline No & Nama responden & $\begin{array}{c}\text { Penerimaan } \\
\text { (Rp/Tahun) }\end{array}$ & $\begin{array}{c}\text { Biaya } \\
\text { (Rp/Tahun) }\end{array}$ & \multicolumn{1}{c}{$\begin{array}{c}\text { Pendapatan } \\
\text { (Rp/Tahun) }\end{array}$} \\
\hline $\mathbf{1}$ & Asis Dg Nyikko & 6.645 .000 & 1.040 .000 & 5.605 .000 \\
$\mathbf{2}$ & Syarifuddin Dg Situru & 3.339 .000 & 480.000 & 2.859 .000 \\
\hline Jumlah & & & 8.464 .000 \\
\hline Rata- rata & & & 4.232 .000 \\
\hline
\end{tabular}

Berdasarkan Tabel 8 menunjukkan bahwa pendapatan petani tergantung luas lahan yang dimiliki oleh petani. Petani dengan pendapatan paling tinggi tinggi yaitu Asis Dg Nyikko dengan luas lahan 0,60 Hektar dengan produksi tahun ini 2215 kilo dijual dengan harga Rp 3000/ kilo maka penerimaan $\mathrm{Rp} \mathrm{6.645.000/Panen} \mathrm{dikurangi} \mathrm{dengan} \mathrm{biaya} \mathrm{berupa} \mathrm{bibit} \mathrm{jagung,} \mathrm{pupuk} \mathrm{urea,} \mathrm{pupuk}$ Za, pupuk NPK, sewa traktor, transpor jadi jumlah biaya sebesar Rp 1.040.000/Panen maka pendapatan yaitu Rp 5.605.000/Panen. Petani Asis Dg Nyikko menerima pendapatan yang lebih tinggi karena memiliki lahan yang cukup luas sehingga produksi yang dihasilkan lebih banyak dibandingkan petani lain.

Penanaman pare pada pola agrisilvikultur ada 2 orang petani penanaman ini dilakukan pinggir tanaman kehutanan, selain memenuhi kebutuhan rumah tangga juga mnghasilkan pendapatan bagi petani sehingga petani menjual sebagian dari yang dihasilkan. Petani menjual pare ke pedagang keliling dengan harga Rp 1000/ buah petani juga menyediakan beberapa bambu untuk landangan pare tersebut pendapatan petani dapat dilihat pada Tabel 9.

Tabel 9. Pendapatan Petani Pare

\begin{tabular}{llccr}
\hline No & Nama responden & $\begin{array}{c}\text { Penerimaan } \\
\text { (Rp/Tahun) }\end{array}$ & $\begin{array}{c}\text { Biaya } \\
\text { (Rp/Tahun) }\end{array}$ & $\begin{array}{c}\text { Pendapatan } \\
\text { (Rp/Tahun) }\end{array}$ \\
\hline $\mathbf{1}$ & Dg Sarro & 640.000 & 120.000 & 520.000 \\
$\mathbf{2}$ & Dg Timung & 680.000 & 140.000 & 540.000 \\
\hline Jumlah & & & 1.060 .000 \\
\hline Rata- rata & & & 530.000 \\
\hline
\end{tabular}

Tabel 9 menunjukkan bahwa petani mendapatkan penghasilan yang lebih tinggi yaitu Dg Timun dengan 4 kali panen dengan jumlah buah 680 buah dengan penerimaan 680.000/Panen dikurangi biaya berupa bibit pare, bambu, pupuk urea jadi jumlah biaya yang dikeluarkan sebesar Rp 140.000/Panen maka pendapatan Rp 540.000/Panen petani Dg Timung menerima pendapatan paling tinggi karena juga memiliki lahan yang lebih luas dibanding petani yang lain.

\section{c. Total Pendapatan Komponen Silvopasture dan Agrisilvikultur}

Total pendapatan merupakan jumlah dari pendapatan yang dihasilkan dari setiap pola agroforestri yaitu pola silvopastura dan agrisilvikultur. Total pendapatan kedua pola tersebut dapat dilihat pada Tabel 10.

Tabel 10. Total Pendapatan Komponen Silvopasture dan Agrisilvikultur

\begin{tabular}{llcc} 
No & Pola Agroforestri & Pendapatan (Rp/Tahun) & Persentase pola agroforestri (\%) \\
\hline 1 & Silvopasture & 5.618 .500 & 47,08 \\
2 & Agrisilvikultur & 6.314 .889 & 52,92 \\
\hline \multicolumn{2}{l}{ Total } & 11.933 .389 & 100,00
\end{tabular}

Berdasarkan Tabel 10 menunjukkan bahwa total pendapatan pola agroforestri di Desa Belapungranga Kecamatan Parangloe Kabupaten Gowa Sulawesi Selatan sebesar Rp 11.933.389/tahun dengan 
persentase $100 \%$, dengan pendapatan pola agroforestri paling besar dari ke dua pola tersebut adalah hasil pola agrisilvikultur sebesar $\mathrm{Rp}$ 6.314.889/tahun atau $52,92 \%$ karena pendapatan dari pertanian dari berbagai jenis dan jangka waktu yang tidak terlalu lama untuk mendapatkan hasil.

\section{KESIMPULAN}

Pola agroforestri yang dikelolah oleh petani di Desa Belapungranga Kecamatan Parangloe Kabupaten Gowa ada dua yaitu pola silvopasture dan pola agrisilvikultur. Pendapatan pola agrisilvikultur Rp 6.314.889/tahun atau 52,92\% dan pendapatan silvopasturer Rp 5.618.500/tahun atau $47.08 \%$, maka pendapatan pola agroforestri paling besar dari ke dua pola tersebut adalah pola agrisilvikultur.

\section{DAFTAR PUSTAKA}

Ainurrasjid. 2001. Agroforestry Suatu Pengantar. Institut Pertanian Malang. Malang

Bahruni. 1999. Diktat Penilaian Sumber Daya Hutan Dan Lingkungan. Fakultas Kehutanan, Institut Pertanian Bogor. Bogor

Dephut,1990. Dalam Social forestry, pusat penelitian dan pengembangan perubahan iklim dan kebijakan.Bogor

Hairiah et al,2003.Dalam Marrtial tri Agrofrestri Pola Pemanfaatan Tanah Berkelanjutan, Graha ilmu. Yogyakarta

Hakim, 2010, Social forestry, pusat penelitian dan pengembangan perubahan iklim dan kebijakan.Bogor

Lahjie,2001. Teknik Agroforestry. UPN Veteran, Jakarta. Di kutip pada skripsi Imran Pendapatan Petani Dengan Sistem Agroforestri di Desa Baroko Kecamatan Baroko Kabupaten Enrekang skripsi Sarjana Kehutanan Fakultas Pertanian dan Kehutanan Universitas muhammadiyah, Makassar. (Tidak di Publikasikan)

Mahendra, F. 2009. Sistem Agroforestry dan Aplikasinya. Penerbit Graha IImu. Yogyakarta.

Mustofa, Djogo, Arifin dan Wijayanto, 2003. Klasifikasi dan Pola Kombinasi Komponen Agroforestri. Bogor, Indonesia

Muthmainnah. 2012. Nilai Manfaat Hutan Pada Catchment Area Das Tanralili Kabupaten Maros. Program Pasca Sarjana, Universitas Hasanuddin. Makassar

Salomon. 2005. Studi Agrosilvopastura Berbasis Lahan. Institut Pertanian Malang. Malang.

Sardjono 2003. Klasifikasi dan pola kombinasi komponen agroforestri. World Agroforestry Centre (ICRAF) Southeast Asia Regional Office.Bogor

Watanabe 1999.Departemen Kehutanan Pusat Bina Penyuluh Kehutanan Hasil Studi Agroforestri departemen kehutanan pusat bina penyuluhan kehutanan. Jakarta

Widianto et al.,2003. Dalam Marrtial tri Agrofrestri Pola Pemanfaatan Tanah Berkelanjutan,Graha ilmu. Yogyakarta 